\title{
BUSINESS MODEL INNOVATION: CREATING VALUE IN TIMES OF CHANGE
}

\author{
Raphael Amit
}

Christoph Zott 


\title{
BUSINESS MODEL INNOVATION: CREATING VALUE IN TIMES OF CHANGE
}

\author{
Raphael Amit ${ }^{1}$ \\ Christoph Zott ${ }^{2}$
}

\begin{abstract}
We highlight business model innovation as a way for general managers and entrepreneurs to create and appropriate value, especially in times of economic change. Business model innovation, which involves designing a modified or new activity system, relies on recombining the existing resources of a firm and its partners, and does not require significant investments in R\&D. We offer managers and researchers a conceptual primer on business model innovation, emphasizing the importance of system-level thinking.
\end{abstract}

JEL Classification: L22, L26, M10

Keywords: Business model, innovation, activity system, design, value creation.

Note: Raffi Amit acknowledges support from the Robert B. Goergen Chair in Entrepreneurship at the Wharton School. Christoph Zott acknowledges financial support from the IESE Research Division. Both authors gratefully acknowledge the financial support of the Wharton-INSEAD Alliance Center for Global Research \& Development. We also thank Cesar Guzman-Concha and Sylvie Beauvais for their valuable research assistance.

\footnotetext{
${ }^{1}$ Professor, The Wharton School, University of Pennsylvania

${ }^{2}$ Professor of Entrepreneurship, IESE Business School
} 


\section{BUSINESS MODEL INNOVATION: CREATING VALUE IN TIMES OF CHANGE}

\section{Introduction}

The central objectives of this article are to depict and illustrate the applicability of business model innovation for value creation and appropriation. In particular,

- We highlight business model innovation as an alternative for general managers and entrepreneurs to create new value, specifically in times of economic change.

- We develop a holistic, multi-dimensional, business model innovation framework that centers on system-level design, as opposed to partial optimization of individual activities, and captures a range of interdependencies within and among business model design elements.

- We attempt to give managers and researchers a "language" for business model innovation that can foster analysis, reflection and dialogue on the subject.

In addressing these objectives, we make three distinct contributions to the literature on business model innovation. First, we analyze and discuss business model innovation through the conceptual lens of activities, which to the best of our knowledge has not been accomplished with the same degree of focus elsewhere. Using the activity system as the level of analysis, and an activity as the unit of analysis, we introduce a set of parsimonious yet operational concepts for academics and managers alike who are interested in better understanding and/or harnessing the power of business model innovation. Second, much of the extant literature on business model innovation has focused on the design of de novo (i.e., new to state-of-the-art) models. The ideas and concepts depicted in this paper are equally applicable to innovators of entirely new business models and to managers of focal firms that need to adapt their business model incrementally with the objective of achieving business model innovation that is new to the focal firm. This could be important for realizing small but meaningful business model improvements (as opposed to revolutionary, game-changing business model breakthroughs), and for improving the firm's competitive position. Last but not least, we contribute to the literature by proposing that even in times of economic crisis and resource scarcity, firms do not need to renounce innovation as a way of enhancing their performance prospects. Rather, managers need to understand the opportunities offered by (relatively cheap) business model innovation to complement, if not substitute (relatively costly) innovation in products or processes. Business model innovation can allow managers to resolve the apparent trade- 
off between innovation costs and benefits by addressing how they do business, for example, by involving partners in new value-creating activity systems.

\section{Innovation in Times of Change}

Companies often make substantial efforts to innovate in their processes and products to achieve revenue growth and to maintain or improve profit margins. Innovations to improve processes and products, however, are often expensive and time-consuming, requiring a considerable investment in everything from $R \& D$ to specialized resources, new assets and even entire new business units. And, in the final analysis, future returns on the up-front investments are always uncertain. These considerations are of particular importance during economic downturns, such as the 2008-2009 global recession. Experts unanimously agree that these were unprecedented times for nearly every firm in nearly every industry in nearly every economic region. With declining revenues and severe pressure on profit margins, many businesses were resorting to drastic cost-cutting in order to survive and position themselves for the next economic upturn. As part of these broad costcutting efforts, many investments in product and process innovation and in market expansion were reduced or even eliminated. In addition, firms often reorganized with the objective of enhancing organizational efficiency by eliminating certain positions and thereby reducing labor costs. While such cost-cutting efforts were needed and understandable and often put firms on a more solid economic footing, the single-minded preoccupation with short-term cost savings often caused anxiety among employees, thereby reducing employee motivation, commitment, and productivity, and might even have hindered the long-term competitiveness of some firms.

Is there a way for managers to innovate in their existing markets with their existing products by utilizing their existing resources and capabilities? Can they extract more value from their firms' existing resources, and, if so, how? Can managers innovate without having to make significant investments in plant, property and equipment (PPE) or in R\&D? In other words, can firms do more with the resources and capabilities they have? In this paper, we suggest that designing a new, or modifying the firm's extant activity system - a process which we refer to as business model innovation - may offer some answers.

\section{The Increasing Importance of Business Model Innovation}

We view a business model as a system of activities that depicts the way a company "does business" with its customers, partners and vendors. More precisely, we define a business model as the bundle of specific activities that are conducted to satisfy the perceived needs of the market, including the specification of the parties that conduct these activities (i.e., the focal firm and/or its partners), and how these activities are linked to each other. ${ }^{1}$ This definition captures the essence of what we believe lies at the heart of the business model concept, namely:

- A focus on the how of doing business, as opposed to the what, when or where;

- A holistic perspective on how business is conducted, rather than a focus on any particular function such as product market strategy, marketing, or operations;

\footnotetext{
${ }^{1}$ Zott, Christoph and Raphael Amit, "Business Model Design: An Activity System Perspective," Long Range Planning, Special Issue on Business Models, 43/2-3 April/May 2010, pp. 216-226.
}

2 - IESE Business School-University of Navarra 
- An emphasis on value creation for all business model participants, as opposed to an exclusive focus on value capture.

- And a recognition that partners can help the focal firm conduct essential activities within its business model.

Our definition is broadly consistent with the various ways in which the term business model is used in practice. ${ }^{2}$ A recently published report from the Economist Intelligence Unit found that a majority of the over 4,000 senior managers who were surveyed worldwide favored new business models over new products and services as a source of future competitive advantage. It stated that, "the overall message is clear: how companies do business will often be as, or more, important than what they do." ${ }^{3}$ And in a similar study conducted by IBM, in which over 750 corporate and public sector leaders from around the world were interviewed on the subject of innovation, "one key finding was that competitive pressures have pushed business model innovation much higher than expected on CEOs' priority list." ${ }^{4}$ Indeed, the study found that outperforming companies whose operating margins had grown faster than their competitors' over the previous five years were twice as likely as their lower-performing peers to emphasize business model innovation, as opposed to product or process innovation. ${ }^{5}$ One CEO explained the importance of business models as a source of innovation by contrasting it with process innovation:

"In the operations area, much of the innovations and cost savings that could be achieved have already been achieved. Our greatest focus is on business model innovation, which is where the greatest benefits lie. It's not enough to make a difference on product quality or delivery readiness or production scale. It's important to innovate in areas where our competition does not act - by developing new competencies, alliances, etc.” ${ }^{6}$

Business model innovation can also help companies stay ahead in the product innovation game, where "you're always one innovation away," as one CEO from another study explained, "from getting wiped out by a new competing innovation that eliminates the need for your product." A good product that is surrounded by a very good business model, however, can stand apart.

Business model innovation is certainly not costless. Consider, for instance, the costs of entering into new strategic partnerships or the often significant costs of intra-organizational change. But these barriers to change can seem less costly in times of economic crisis when capital resources to fund substantial R\&D are scarce. In fact, the propensity to question the status quo and the willingness to consider organizational changes can be particularly high in times of intense economic pressures, as any new source of value creation may be particularly attractive during times of resource scarcity. Moreover, although business model innovation is often facilitated by

\footnotetext{
${ }^{2}$ For a recent review of business model definitions, see Zott, Christoph, Raphael Amit, and Lorenzo Massa, "The Business Model: Theoretical Roots, Recent Developments, and Future Research”, Working Paper, IESE Business School, 2010.

3 "Business 2010: Embracing the Challenge of Change," Economist Intelligence Unit (2005).

${ }^{4}$ Pohle, George and Marc Chapman, "IBM’s Global CEO Report 2006: Business Model Innovation Matters”, Strategy \& Leadership, 34/5 (2006): pp. 34-40.

${ }^{5}$ Pohle and Chapman, op. cit., p. 36.

${ }^{6}$ Pohle and Chapman, op. cit.

7 “Economist Intelligence Unit”, op. cit., p. 10.
} 
technological innovations, such as the Internet or broadband communication, which enable firms to organize and interact in new ways, business model innovators do not need to commit R\&D investments to these technologies. Rather, they deploy technologies in innovative ways.

\section{Business Model Innovation in Practice}

To illustrate the concept of business model innovation, consider the case of Apple. For most of its history, the company had been focused on the production of innovative hardware, mostly personal computers. By creating the iPod and the associated music download business iTunes, however, Apple was the first electronics company to include music distribution as an activity, linking it to the development of the iPod hardware and software. Apple thereby pushed many subactivities of legal music downloads to its customers, thus avoiding or reducing additional costs for the firm, while offering a new service. Rather than growing by simply bringing a new hardware product to the market, Apple radically transformed its business model to include an ongoing relationship with its hardware customers (similar to the "razor and blade" model of companies such as Gillette). In this way, Apple expanded the locus of its innovation from the product space to the business model. Figures 1 and 2 illustrate, respectively, the revenues and profit change at Apple Inc. after the introduction of the iTunes/iPod business model, and the stock price change after the introduction of the new business model.

\section{Figure 1}

Revenues and Net Income of Apple (Before \& After Business Model Change)

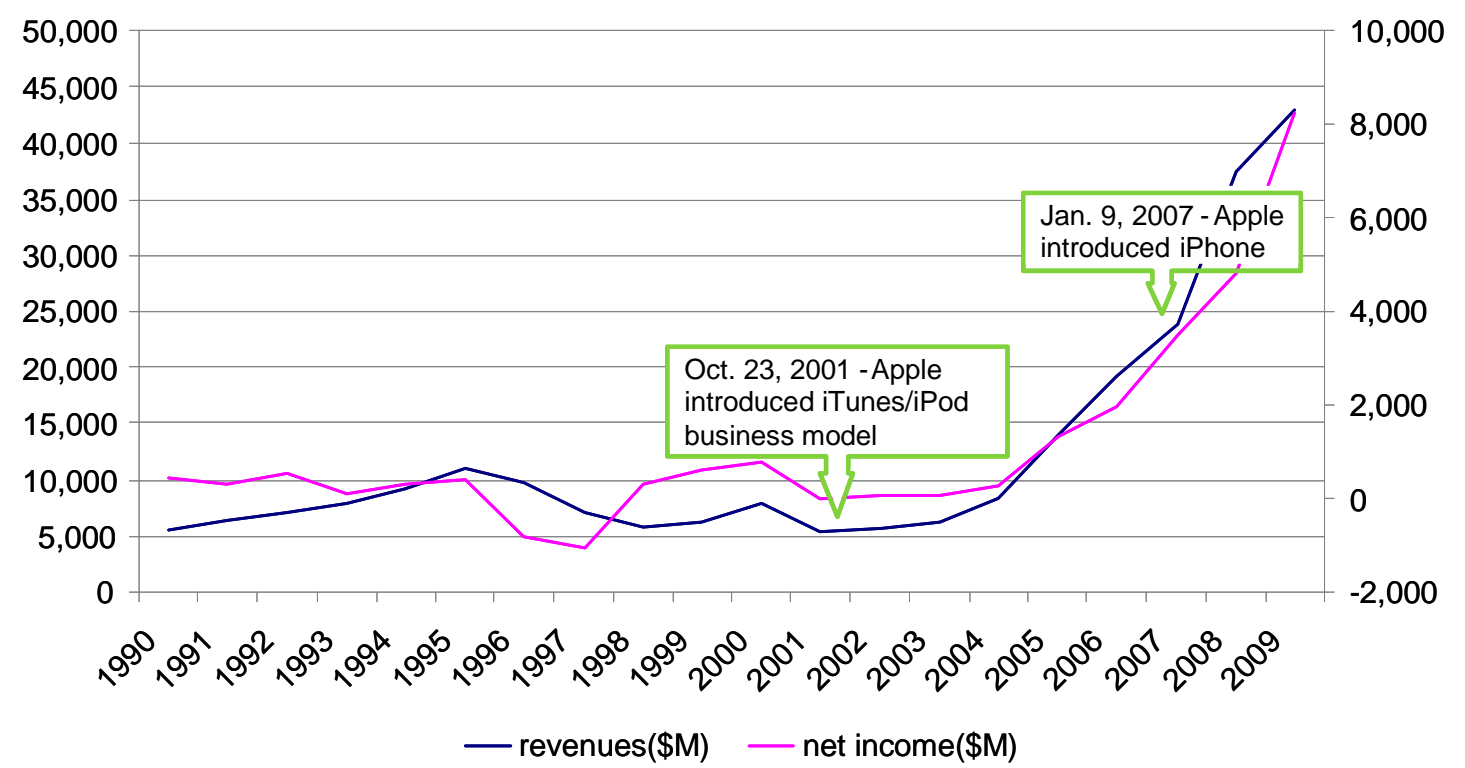




\section{Figure 2}

Stock Price of Apple (Before \& After Business Model Change)

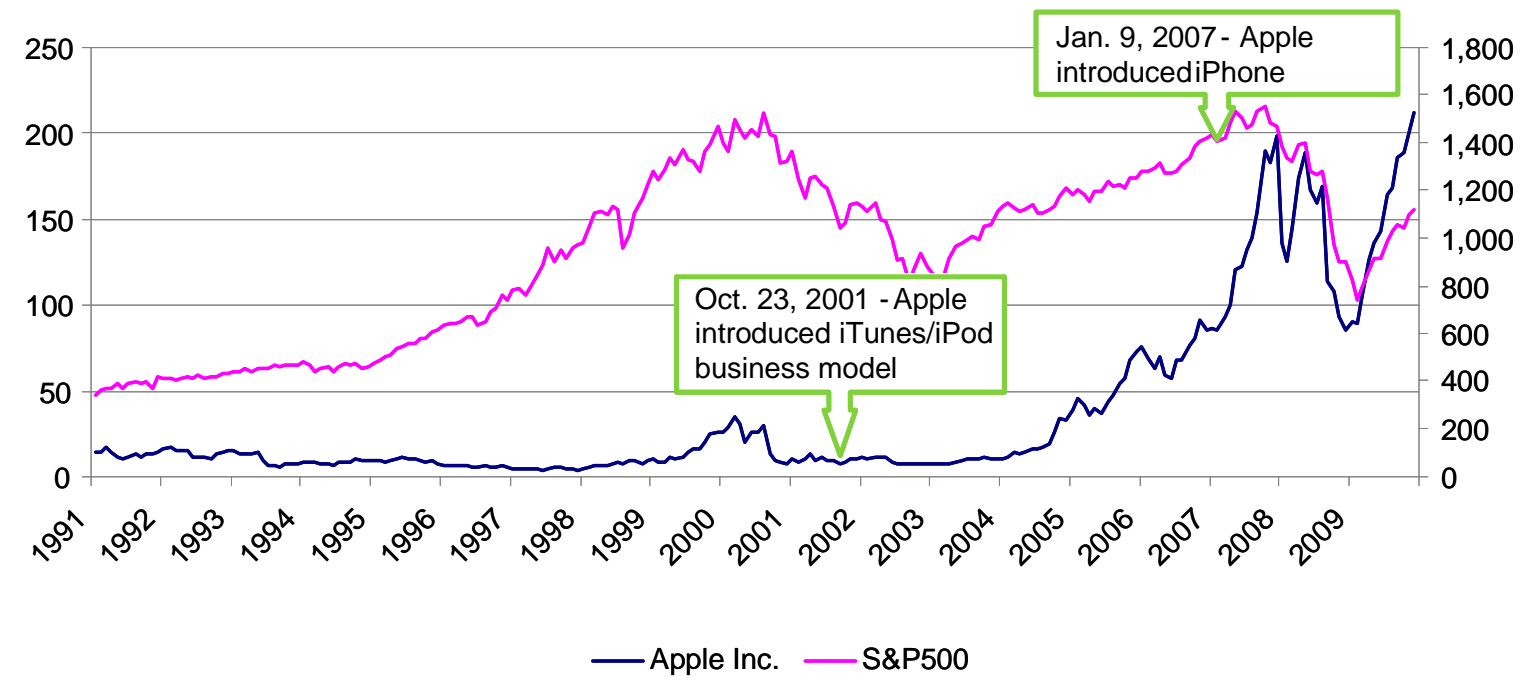

As another example, consider the fashion retailer Inditex, a fast-growing Spanish firm that manages global brands such as Zara. The firm has made business-model thinking a corporate priority. Their 2007 Annual Report begins by explaining the Inditex business model and highlighting its innovative elements. Inditex has made many choices that, viewed in isolation, seem inefficient. For example, for their Zara business, they perform many generic activities inhouse, such as dyeing and cutting the fabric, and washing, ironing, and ticketing the finished garments. Moreover, they outsource sewing to small workshops located close to their Spanish production facilities. When viewed in isolation, these choices seem inefficient, hence questionable. As a whole, however, their carefully designed activity system allows Inditex to bring new fashionable garments from the design stage to the shop floor within record time days as opposed to months - which makes a big difference in the fast-moving fashion business. Although its competitors have much stronger track records and capabilities in product innovation and logistics, Inditex beats them to the punch through its innovative business model, which relies on standard resources (e.g., people who spot new trends, but do not create them) and off-the-shelf technologies (e.g., standard communication technologies for transmitting real-time feedback from the retail shops to the design teams), but which deploys these resources in activities that are linked and governed in novel ways.

Managers and entrepreneurs as well as academics should be interested in business model innovation for several reasons. First, it represents an often overlooked (and hence underutilized) source of future value for businesses - a way of creating new or enhanced revenues and profits at relatively low cost. Second, competitors might find it difficult to imitate and/or replicate an entire novel activity system; it is much easier to copy a single novel product or process. Since it is relatively easier to undermine and erode the returns from product or process innovation, innovation at the business model level can translate into a sustainable performance advantage. Third, because business model innovation can be such a potentially powerful competitive tool, 
managers must be attuned to the possibility of competitors' efforts in this area. ${ }^{8}$ They must learn to identify competitive threats that may come from beyond their traditional industry boundaries (as illustrated by Apple's entry into the music business from the electronics and computer business, which was enabled by its business model innovation).

In the next section, we describe the conceptual underpinnings of business model innovation, and then move on to explain our concepts, from which we will distill six questions managers need to ask to initiate business model innovation. The usefulness of this framework is illustrated with some examples, notably McGraw-Hill company (a publisher) and The Gap (a fashion retailer).

\section{The Conceptual Underpinnings of Business Model Innovation ${ }^{9}$}

Rapid advances in information and communication technologies have facilitated new types of technology-mediated interactions between economic agents. These developments have enabled firms to fundamentally change the ways they "do business," in particular, the ways they organize and conduct exchanges and activities across firm and industry boundaries with customers, vendors, partners and other stakeholders. Because of these technological advances, senior managers of focal firms have increased the number of options in how they structure their networks. They can innovatively design (i.e., construct, link, sequence) boundary-spanning exchanges and activities. This design is captured by the firm's business model.

The overall objective of a focal firm's business model is to satisfy a perceived need in order to create value for the focal firm and its partners. ${ }^{10}$ That objective could also be called "the valuecreating insight on which the firm turns," and it is reflected in the customer value proposition. ${ }^{11}$ As highlighted in the introduction, a focal firm's business model is defined as an activity system that is designed and enabled by a focal firm, but which transcends the focal firm and spans its boundaries. ${ }^{12}$ It encompasses activities that are conducted either by the focal firm or by its partners, customers, or vendors.

The business model concept has rich conceptual roots. Scholars have conceptualized the phenomenon in different ways and viewed it from various theoretical angles. In one research

\footnotetext{
${ }^{8}$ Casadesus-Masanell, Ramon and Joan Enric Ricart, “Competing through Business Models,” Working Paper No. 713 , IESE Business School, 2007.

${ }^{9}$ In this section, we focus on the business model as a source of innovation in and of itself. There is also a literature on how business models help companies benefit from technological innovation. Consider, for example, the research of Chesbrough on what he calls "open business models," which essentially captures the idea that certain features of business models can help firms draw more heavily on external sources of technological innovation (see Chesbrough, Henry "Open Business Models," Boston, MA: Harvard Business School Press, 2006). And through a series of cases, Loch et al. (e.g., see Loch, Christoph, Christoph Zott, Amir Guttman, Paivi Jokela, and Doron Nahminas "FriCSo (A): How to Translate a New Technology Into a Business (Model)?" Case, INSEAD, 2008) explore how a startup company with an extremely promising technology needs to find the right business model to reap commercial rewards from its technological innovation. What these works have in common is that the business model can be a conduit for other types of innovation.

10 Amit, Raphael and Christoph Zott, "Value Creation in e-business," Strategic Management Journal, 22/6-7, June/July 2001, pp. 493-520.

${ }^{11}$ Magretta, Joan “Why Business Models Matter," Harvard Business Review, 80/5 May 2002, pp. 86-92.

${ }^{12}$ Zott, C. and R. Amit (2010), op. cit.
} 
stream, Chesbrough and Rosenbloom link the business model to the technology management literature and define it as the "heuristic logic that connects technical potential with the realization of economic value," emphasizing its role in linking technology to market outcomes. ${ }^{13}$ Consistent with this perspective, Casadesus-Masanell and Ricart posit that one important component of business models are the choices made by management in how the organization operates, such as compensation practices, procurement contracts, location of facilities, or assets employed. ${ }^{14}$ Another component of business models, according to this view, are the consequences of these choices, such as low cost or culture of frugality, which describe the firm's logic.

Other scholars have promoted a more parsimonious view of the business model. McGrath, for example, suggests thinking about business models by using two core ideas concerning managerial choices: units of business (i.e., what you are selling that someone is prepared to pay for), and the set of activities employed to sell those units. ${ }^{15}$ Indeed, the idea of business models as boundary-spanning systems of transactions and activities has been developed in a series of articles by Amit and Zott to capture the essence of "how firms do business." ${ }^{16}$ These researchers have begun to describe the business model as a source of innovation, for example, when it connects previously unconnected parties, links transaction participants in new ways, or introduces new transaction mechanisms. Business model innovation thus conceived may complement innovation in products and services, production, distribution or marketing methods, and markets. ${ }^{17}$ An innovative business model can either create a new market or allow the firm to create and exploit new opportunities in existing markets. Dell, for example, implemented a customer-driven build-to-order business model, which replaced the traditional build-to-stock model of selling computers through retail stores. ${ }^{18}$

More precisely, Amit and Zott defined the business model as "the content, structure, and governance of transactions designed to create value through the exploitation of business opportunities." ${ }^{19}$ Transaction content refers to what is being exchanged, transaction structure refers to how the exchanges are linked, and transaction governance refers to issues of control. The researchers found through large-sample, cross-sectional empirical analysis that business model innovation conceived as novel (i.e., new to the state-of-the-art) transaction architectures positively influences firm performance, even when the environment switches from resource-rich

13 Chesbrough, Henry and Richard Rosenbloom, "The Role of the Business Model in Capturing Value from Innovation: Evidence from Xerox Corporation's Technology Spinoff Companies," Industrial and Corporate Change, 11/3 June 2002, pp. 533-534.

${ }^{14}$ Casadesus-Masanell, Ramon and Joan Enric Ricart, "From Strategy to Business Models and on to Tactics," Long Range Planning, Special Issue on Business Models, 43/2-3, April/May 2010, pp. 195-215.

${ }^{15}$ McGrath, Rita Gunter "Business Models: A Discovery Driven Approach, "Long Range Planning, Special Issue on Business Models, 43/2-3, April-June 2010, pp. 247-261.

${ }^{16}$ Amit and Zott op. cit.; Zott, Christoph and Raphael Amit, "Business Model Design and the Performance of Entrepreneurial Firms,” Organization Science, 18/2, March-April 2007, pp. 181-199; Zott, Christoph and Raphael Amit, "The Fit Between Product Market Strategy and Business Model: Implications for Firm Performance," Strategic Management Journal, 29/1, August 2008, pp. 1-26.

${ }^{17}$ Schumpeter, Joseph "The Theory of Economic Development: An Inquiry into Profits, Capital, Credit, Interest, and the Business Cycle," (Cambridge, MA: Harvard University Press, 1934, Reprint 1996).

${ }^{18}$ Brynjolfsson, Eric and Lorin Hitt, "Intangible assets and the economic impact of computers," in "Transforming Enterprise,” (eds.), William Dutton, et al. (Boston, MA: MIT Press, 2004), pp. 27-48.

${ }^{19}$ Amit and Zott, op. cit., p. 511. 
to resource-poor. ${ }^{20}$ They also established empirically that business model innovation is distinct from product differentiation, and that both business model innovation and product innovation interact positively (i.e., act as complements) in influencing firm performance. ${ }^{21}$ But that research examined business models ex-post using reflective measures of business model innovation, such as patents applied for or patents already accorded on business methods. In this paper, we develop a conceptual primer to allow managers to analyze and design novel business models ex-ante.

Much of the prior research on business model innovation, moreover, has considered the extent to which business models are de-novo, i.e., new to the state-of-the-art, and not just new to the firm. ${ }^{22}$ Nidumolu, Prahalad and Rangaswami view the development of new business models as a key step in their five-stage model of corporate transformation to become environmentally sustainable. ${ }^{23}$ They declare as the central challenge "to find novel ways of delivering and capturing value, which will change the basis of competition." ${ }^{24}$ According to the authors, opportunities for business model innovation lie in developing new delivery technologies that change the value chain, in combining digital and physical infrastructures, or in turning products into services. Similarly, Johnson, Christensen and Kagermann focus on de-novo business models, based on the belief that there is "no point in instituting a new business model unless it is not only new to the company, but in some way game-changing to the industry or market." ${ }^{25}$

Changes to business model design, however, can be subtle; they may not have the potential to disrupt an industry, but could still yield important benefits to the business model innovator (i.e., the focal firm). Consider Taco Bell, the restaurant chain offering Mexican-style fast food, which in the late 1980s decided to turn the restaurant's kitchen into a heating and assembly unit in a program called "K-minus." The chopping, cooking and clean-up activities were transferred to corporate headquarters. The food was sent pre-cooked in plastic bags to restaurants, where it could be heated, assembled and served. ${ }^{26}$ This incremental business model innovation was not game-changing for the fast-food industry, but it allowed Taco Bell to realize economies of scale and improvements in efficiency and quality control, as well as increase space for customers within the restaurants. ${ }^{27}$ Other firms might wish to change their business models in similar (incremental) ways, or follow a business model innovator in their industry in order to achieve competitive parity.

Some scholars have suggested very broad domains for business model innovation, in line with their corresponding definitions of the business model concept. Mitchell and Coles, for example, propose that business model innovation involves modifications in the "who," "what," "when,"

\footnotetext{
${ }^{20}$ Zott and Amit (2007), op. cit.

${ }^{21}$ Zott and Amit (2008), op. cit.

22 Birkinshaw, Julian, Gary Hamel and Michael Mol, "Management Innovation," Academy of Management Review, 33/4, October 2008, pp. 825-845.

${ }^{23}$ Nidumolu, Ram, C. K. Prahalad and M. R. Rangaswami, "Why Sustainability Is Now the Key Driver of Innovation," Harvard Business Review 87/9, September 2009, pp. 57-64.

${ }^{24}$ Nidumolu et al., op. cit., p. 60

25 Johnson, Mark, Clayton Christensen and Henning Kagermann, "Reinventing your Business Model," Harvard Business Review, 86/12, December 2008, p. 58.

${ }^{26}$ See Applegate, Lynda, Leonard Schlesinger and David Delong, "Taco Bell, Inc." Case \# 1983-94 (Harvard Business School, 2001).

${ }^{27}$ Santos, José, Bert Spector and Ludo Van Der Heyden, "Toward a Theory of Business Model Innovation within Incumbent Firms," Working Paper \#2009/16/EFE/ST/TOM (INSEAD, 2009).
} 
"why," "where," "how," or "how much" involved in providing products and services to customers. ${ }^{28}$ Similarly, Johnson et al.'s notion of business model innovation involves the firm's value proposition, target customers, product and service offering, resources (such as people, technology or equipment), revenue model, cost structure, processes, rules and norms. ${ }^{29}$

Although such broad views of the domain of business model innovation can have their merits (e.g., they allow consideration of interesting dynamics such as feedback loops), ${ }^{30}$ we suggest that a focus on the activity system as the level of analysis, and on the activity as the unit of analysis for business model innovation, fosters conceptual clarity and enhances operational simplicity. At the same time, it allows for capturing essential stylized facts of the phenomenon such as a focus on the how of doing business, a holistic and systemic perspective on how business is conducted, an emphasis on value creation, and the importance of partners who help the focal firm conduct essential activities within its business model. Furthermore, an activity system perspective on business models acknowledges the importance of interdependencies among activities.

Interdependencies exist when activities, taken together, have a different impact on an objective function (e.g., performance) than each of the activities considered in isolation. ${ }^{31}$ Interdependencies are created by entrepreneurs or managers in several ways: when they choose the set of organizational activities they consider relevant to satisfying a perceived market need; when they design the links that weave activities together into a system; and when they shape the governance mechanisms that hold the system together. The business model thus captures how the focal firm through its activity system is embedded in its "ecology," i.e., in its multiple networks of suppliers, partners and customers. It also defines who are the firm's potential suppliers, partners and customers (and competitors). These important consequences of a firm's business model design choice have obvious ramifications on its ability to create and capture value. The stronger the competition implied by the choice of the business model, for instance, the more difficult value creation becomes.

\section{How to Innovate the Business Model: A Conceptual Primer}

Important design elements that characterize an activity system are its content, structure, and governance. ${ }^{32}$ These elements can be leveraged - individually as well as jointly - to engender business model innovation.

Business model design elements. The content of an activity system refers to the selection of activities to be performed. For example, Bancolombia adopted activities beyond those of a typical retail bank. The perceived market need for these activities was the demand for microcredit of the more than $60 \%$ of Colombians who did not have access to banking services. To perform these new activities - an innovation in the content of its business model - the bank

\footnotetext{
28 Mitchell, Donald, and Carol Coles, "The Ultimate Competitive Advantage of Continuing Business Model Innovation," Journal of Business Strategy, 24/5 (2003), pp. 15-21.

${ }^{29}$ Johnson, Christensen, and Kagermann, op. cit.

${ }^{30}$ As described in Casadesus-Masanell and Ricart (2010), op. cit.

${ }^{31}$ Siggelkow, Nicolaj "Change in the Presence of Fit: The Rise, Fall, and the Renaissance of Liz Clairborne," Academy of Management Journal, 44/4, August 2001, pp. 838-857. Siggelkow, Nicolaj "Evolution toward Fit," Administration Science Quarterly, 47, March 2002, pp. 125-159.

${ }^{32}$ Amit and Zott, op. cit.
} 
needed to train its top management, hire and train new staff, and link the new activities to its existing system (platforms, applications, and channels)..$^{33}$ Another example of business model innovation focused on content is IBM. ${ }^{34}$ Triggered by a severe financial crisis in the early 1990s, the firm shifted its focus from being a supplier of hardware to becoming a service provider. Drawing on know-how built over decades, IBM launched a range of new activities in consulting, IT maintenance, and other services. As a result, more than half of IBM's $\$ 96$ billion in revenues in 2009 came from these activities, which had barely existed 15 years earlier.

The structure of an activity system describes how the activities are linked, e.g., the sequencing of activities and the exchange mechanisms among the linked activities. Consider Priceline.com. This online travel agency has established links with airline companies, credit card companies, and the Worldspan Central Reservation System, among others. By introducing a reverse market in which customers post desired prices for sellers' acceptance, the firm has fundamentally innovated the exchange mechanism through which these parties interact and by which items such as airline tickets are sold. Priceline.com has been granted a business method patent on its innovative activity system. The system's novel structure distinguishes the firm from other travel agencies.

The governance of an activity system refers to who performs the activities. Franchising, for example, represents one possible approach to innovative activity system governance. It can be the key to unlocking value, as was the case for Japanese retailing when entrepreneur Toshifumi Suzuki realized in the early 1970s that the franchise system developed in the United States was an ideal response to the strict regulations imposed by the Japanese government on retailing outlets (e.g., limiting their size and restricting opening times). By franchising Seven-Eleven stores in Japan, Suzuki adopted a novel type of activity system governance and managed to create value through professional management and local adaptation. ${ }^{35}$ Another example of an innovative governance structure is the recent formation of a consortium of magazine publishers, including Time Inc., Hearst, Meredith, and Condé Nast, to develop an online magazine newsstand using multiple digital formats. This company, jointly owned by industry rivals, is sometimes characterized as the "iTunes for magazines." It is a response by rival publishers to the declining print circulation and hence advertising revenue and the growth of digital media. ${ }^{36}$ Ann Moore, the Chairwoman of Time Inc, recently stated that, "It's increasingly clear that finding the right business model is crucial for the future of our business." ${ }^{37}$

Interdependencies among business model design elements. These three business model design elements (content, structure and governance) can be highly interdependent. Take the United Statesbased P2P lending company, Prosper, for example. The venture aims at enabling direct, small, unsecured loans between individual lenders and borrowers. The founders of Prosper made the conscious decision at an early stage to let lenders choose the borrowers to whom they wanted to lend their money. This was a structural choice (settling the question of how lending and borrowing activities were linked), but it also constituted a decision about governance because the evaluation and selection activities were shifted to the customers, and were not performed by the firm.

\footnotetext{
${ }^{33}$ Banerjea, Sunny et al., "Dare To Be Different. Why Banking Innovation Matters Now," (Somers, NY: IBM Global Services, 2006).

${ }^{34}$ Chesbrough, op. cit.

${ }^{35}$ Nagayama, Kei, and Peter Weill, “7-Eleven Japan Co. Ltd.: Reinventing the Retail Business Model,” (CISR Working Paper no. 338, Sloan School of Management, MIT, 2004).

${ }^{36}$ New York Times, Page B3, November 25, 2009.

${ }^{37}$ New York Times, op. cit.
} 
Accordingly, managers can innovate on all three business model design elements-content, structure, and governance-individually as well as jointly. For example, consider again P2P lending companies like Prosper, Lending Club or Zopa. Important business model design issues for the founders in the early stages of these firms were whether to include a secondary market for trading loans in their activity systems (a content issue); how precisely to link borrowing and lending activities - for example, would they provide an algorithm that automatically matched borrowers to lenders, and if so, to whom and to how many - (a structure issue); and who should perform the credit risk assessment on the borrower, the P2P firm or the lender (a governance issue)?

Interdependencies between business and revenue models. In addition to the interdependencies among business model design elements, one needs to consider another type of interdependency, namely, that between a firm's business model and its revenue model. The revenue model refers to the specific ways a business model enables revenue generation for the focal firm. ${ }^{38}$ It is the way in which the focal firm appropriates some of the value that is created by the business model for all its stakeholders. A revenue model complements a business model design, just as a pricing strategy complements a product design. Consider for example Better Place whose business model aims at providing Electric Vehicle (EV) services. Just like a mobile phone operator whose business model centers on enabling the use of the mobile phone device through its network rather than on the mobile phone itself, the business model of Better Place centers on providing EV networks and services rather than on the electric vehicle itself. It involves an innovative business model structure with partners ranging from governments, vehicle manufacturers, clean energy producers, and others. And just as mobile phone operators charge customers variable or flat rates for telecommunication services, Better Place intends to implement a revenue model as a function of customers' car usage (miles driven), thus taking into account the interdependency between its business and revenue models. ${ }^{39}$

Although the concepts of business and revenue model may be quite closely related and are sometimes even inextricably intertwined - for example, in the product world, Gillette uses its pricing strategy of selling cheap razors to make customers buy its rather expensive blades business models and revenue models are conceptually distinct. A business model is geared toward total value creation for all parties involved. It lays the foundations for the focal firm's value capture by co-defining (along with the firm's products and services) the overall "size of the value pie," which can be considered an upper limit to the firm's value capture. ${ }^{40}$ The business model also co-determines the focal firm's bargaining power. The greater the total value created, and the greater the focal firm's bargaining power, the greater the amount of value that the focal firm can appropriate. ${ }^{41}$ How much of the possible total value is actually captured, however, depends on its pricing strategy or its revenue model.

Caveats. We also offer the following conceptual caveats for business model innovators. When designing their firms' new activity systems, managers need to bear in mind that identifying technologically and/or strategically distinct activities can be conceptually challenging because the number of potential activities is often quite large. ${ }^{42}$ Many seemingly inseparable activities

\footnotetext{
${ }^{38}$ Amit and Zott, op. cit.

${ }^{39} \mathrm{http}: / /$ www.betterplace.com/company/

40 Brandenburger, Adam, and Harborne Stuart, "Value-based Business Strategy," Journal of Economics and Management Strategy, 5/1, March 1996, pp. 5-25.

${ }^{41}$ Zott and Amit (2007), op. cit.

${ }^{42}$ Porter, M. E., “Competitive Advantage: Creating and Sustaining Superior Performance,” (New York: The Free Press, 1985).
} 
can be broken down even further, especially given ongoing advances in information and communication technologies. ${ }^{43}$ One way to deal with this issue is to define activities at different levels of aggregation. Davenport, for example, mentions the supply chain operations reference model, which lays out top-level activities (plan, source, make, deliver, and return), and also specifies sub-activities that can be delineated at second, third, and fourth levels. ${ }^{44}$ At high levels of aggregation, activities could comprise whole business functions, such as accounting, or human resource management. At low levels of aggregation (i.e., high levels of decomposition), activities could be as specific as the processing of customer e-mails based on their content, or the translation of product manuals into a foreign language.

Also, changing the whole activity system rather than optimizing individual activities (such as production) requires systemic and holistic thinking, which can be demanding. When responding to a crisis, operating in tough economic times, or when taking advantage of a new opportunity, rethinking an entire business model may not always be at the top of a manager's mind. This will be particularly true when the level of resistance to change is predicted to be high. Therefore, choices on business model design often go unchallenged for a long time.

\section{The Questions Managers Need to Ask for Business Model Innovation}

Innovation need not be simply about new product lines or improved processes, but can also relate to the organization of a firm's activities, specifically, their content, structure and governance. Indeed, our own research shows that in a highly interconnected world, especially in a world where financial resources are scarce, entrepreneurs and managers must look beyond the product and process levels to focus on ways to innovate their business model. This can help them create and exploit opportunities for new revenue and profit streams to counteract declining revenues and pressures on profit margins and position themselves for the next economic upturn. ${ }^{45}$ In this regard, we suggest that managers ask themselves the following six key questions:

1. What is the objective of the new business model? In other words, what perceived needs would be satisfied through the design of a new activity system?

2. What novel activities are needed to satisfy the perceived needs? (Business model content.)

3. How could these activities be linked to each other in novel ways? (Business model structure.)

4. Who should perform each of the activities that are part of the business model (e.g., the focal firm, or a partner), and what novel governance arrangements could enable this structure? (Business model governance.)

5. How is value created through the novel business model for each of the partners?

6. What focal firm's revenue model will allow it to appropriate part of the value created from the new business model?

\footnotetext{
${ }^{43}$ Santos, Filipe, "Toward an Entrepreneurial Theory of Boundaries: The Scalability of Firms in Nascent Markets" (Working Paper, INSEAD, 2006).

${ }^{44}$ Davenport, Tom, “The Coming Commoditization of Processes," Harvard Business Review, 83/6, June 2005, pp. 100-108.

${ }^{45}$ Zott and Amit (2007), op. cit.; Zott and Amit (2008), op. cit.
} 
To illustrate how managers might address these questions, consider the business model of the McGraw Hill book publishing business. ${ }^{46}$ The book market comprises publishers of academic, professional, general and other trade books. In the United States, the latter items (consumer titles and celebrity authors' books) represent about 55\% of the market's revenues, while the remainder is generated by academic and professional books. Until very recently, websites have only been a real marketing platform for digital content for the business-to-business and academic texts segments. While e-readers such as the Kindle and the iPad are rapidly gaining popularity, the time consuming and expensive book-publishing process has not changed in a material manner in many decades. The growing interest in electronic formats has been stimulated by competing players in the area of providing information and content, such as Google or Amazon. Publishers in the United States and Europe are searching for solutions to meet the emerging demand for creating and delivering digital content on portable devices while preserving, and in fact enhancing, value. The objective is to design a new business model which will enable companies such as McGraw Hill to capture this perceived need.

Meeting the perceived need may require publishers to perform new activities. Although it is unlikely that the traditional hardback/paperback book will disappear, it is expected that the demand for printed publications will fall sharply. If printing and physical distribution become less relevant in the process, the time it now takes to add a new title to a catalogue and to bookstore shelves will be reduced. Accordingly, designing, uploading and maintaining the most complete online catalogue would be a central new activity in publishers' business models. In addition, to the extent that publishers will bypass the retail bookstores (such as Borders) in their new business models, they will have to develop a new marketing activity for retail buyers. Another activity that will have to be included in a new business model will be the replacement of the manual process of creating content with a digitally enabled streamlined process (new business model content).

Linking the various activities to each other, sequencing these linkages, and deciding on the exchange mechanisms in the new business models require careful consideration. For example, the exchange mechanism chosen with multiple digital distribution partners such as Apple and Amazon, through which McGraw Hill distributes digital content to retail consumers, will affect the breadth of McGraw Hill's access to the retail digital book market. Designing the linkages among authors, editors, and other publishing professionals and the distributors will also be an essential part of the new business model. These linkages must reflect alternatives available to authors, such as bypassing publishers all together, as well as approaches adopted by competing publishers (new business model structure).

Determining whether McGraw Hill or another partner will carry out each of the new business model's activities requires consideration of multiple tradeoffs. For example, will content be delivered through a new McGraw Hill branded device, or by proprietary devices offered by partners such as Amazon (with its Kindle), or Apple (with its iPad) and thereby leveraging their position in the market? Or will content be delivered through Internet-based platforms that are compatible with a broad range of devices and enable global distribution? These are crucial decisions in the design of the new business model (new business model governance).

\footnotetext{
${ }^{46}$ The McGraw-Hill Companies (NYSE: MHP) are active in the financial services, education and business information markets through leading brands such as Standard \& Poor's, McGraw-Hill Education and J. D. Power and Associates. In this section, we focus on the book publishing business.
} 
The value that will be generated through publishers' new business models will be created through the complementarities and interdependence among activities, and through the enormous efficiencies in the publishing process that the new business model enables. A number of alternative revenue models associated with these new business models could be considered, such as a single subscription price independent of the number of manuscripts downloaded, piecemeal pricing, and/or value-based pricing for time-sensitive publications.

Another illustration of how managers of established firms might address the questions for business model innovation is provided in Table 1, which illustrates our framework using the United States fashion retailer The Gap. ${ }^{47}$

\section{Table 1}

Business Model Innovation Alternatives for the GAP

\begin{tabular}{|c|c|c|}
\hline Questions & The GAP: Current Business Model & $\begin{array}{l}\text { The GAP: Alternatives For New } \\
\text { Business Model }\end{array}$ \\
\hline $\begin{array}{l}\text { 1. What is the objective of the } \\
\text { (new) business model? What } \\
\text { perceived needs are satisfied? }\end{array}$ & $\begin{array}{l}\text { Provide clothing, accessories and } \\
\text { personal care products for men, } \\
\text { women and children, through } 5 \text { brands }\end{array}$ & $\begin{array}{l}\text { Provide high-quality "fast fashion" at } \\
\text { affordable prices for each of the } 5 \text { brands } \\
\text { to each addressable market segment }\end{array}$ \\
\hline $\begin{array}{l}\text { 2. What (novel) activities are } \\
\text { needed to satisfy the } \\
\text { perceived needs? (Business } \\
\text { model content) }\end{array}$ & $\begin{array}{l}\text { Design and merchandising; planning } \\
\text { and sourcing; production; marketing; } \\
\text { distribution; sales and analysis }\end{array}$ & $\begin{array}{l}\text { - Observing customer behavior in } \\
\text { shops and digitally transmitting data } \\
\text { in real time to design team } \\
\text { - Customized garment design \& } \\
\text { manufacturing including menus of } \\
\text { alternative styles }\end{array}$ \\
\hline $\begin{array}{l}\text { 3. How are these activities linked } \\
\text { to each other (in novel ways)? } \\
\text { (Business model structure) }\end{array}$ & $\begin{array}{l}\text { Linear "step-by-step" approach that } \\
\text { determines a seasonal cycle from } \\
\text { designing to selling a garment. }\end{array}$ & $\begin{array}{l}\text { - Link feedback from stores and } \\
\text { scouting of competition to design } \\
\text { team; "closed loop" approach } \\
\text { - Link customer measurements, } \\
\text { garment style and garment } \\
\text { preference to manufacturing }\end{array}$ \\
\hline $\begin{array}{l}\text { 4. Who performs each of the } \\
\text { activities that are part of the } \\
\text { business model? (Business } \\
\text { model governance) }\end{array}$ & $\begin{array}{l}\text { Most activities performed in-house, } \\
\text { except for manufacturing (outsourced) } \\
\text { and marketing (external advertising } \\
\text { agency) }\end{array}$ & $\begin{array}{l}\text { - Mix of in-house and outsourced } \\
\text { manufacturing } \\
\text { - For example, in-house cutting and } \\
\text { sewing (flexibility) }\end{array}$ \\
\hline $\begin{array}{l}\text { 5. How is value created through } \\
\text { the (novel) business model for } \\
\text { each of the partners? }\end{array}$ & $\begin{array}{l}\text { By meeting customer demand for } \\
\text { basic styles and garments and by } \\
\text { efficiently managing the supply chain }\end{array}$ & $\begin{array}{l}\text { - By offering new designs and } \\
\text { fashion exclusivity to customers } \\
\text { (deeper penetration of current } \\
\text { segments \& penetration of new } \\
\text { segments) } \\
\text { - By increasing turnover rates }\end{array}$ \\
\hline $\begin{array}{l}\text { 6. What focal firm revenue } \\
\text { model allows it to appropriate } \\
\text { part of the value created from } \\
\text { the (new) business model? }\end{array}$ & Competitive pricing for basic designs & $\begin{array}{l}\text { - Premium pricing for customized } \\
\text { merchandise } \\
\text { - Premium pricing for "hot" new } \\
\text { designs }\end{array}$ \\
\hline
\end{tabular}

${ }^{47}$ See Gap Inc., Annual Report 2009. Data monitor, Company profile: Gap Inc. 2008, in Datamonitor.com (accessed June 22, 2010); Gap, Inc. Website, http://www.gapinc.com, (accessed June 22, 2010). 


\section{Conclusion}

In this article, we contend that in order to innovate their business model designs, managers should realize that:

- Business models are boundary-spanning systems of activities centered on a focal firm.

- There are numerous interdependencies among the activities in a business model and among business model design elements, including how content, structure and governance interrelate.

- And, business models create value for all the parties involved (the focal firm, its partners, suppliers and customers). In order to capture an amount of that value, focal firms need to adopt an appropriate revenue model.

Addressing the six questions outlined above will allow managers to better understand how they can structure their firms' destinies within the context of the networks and ecosystems in which they are embedded. The active design and construction of an activity system, which encompasses internal as well as boundary-spanning activities, are key tasks for general managers and entrepreneurs. Without the business model perspective, the focal firm is a mere participant in a sometimes dazzling array of networks and passive entanglements. Adopting the business model perspective helps managers and entrepreneurs purposefully structure their firms' activity systems in cooperation and interdependence with other firms and economic agents in their ecosystems. This purposeful design and structuring of business models can be an important source of innovation, particularly during periods of change and resource scarcity, high uncertainty and volatility in both capital and real markets that adversly affect revenues and profits.

Most importantly, perhaps, the perspective advanced in this article encourages systemic and holistic thinking when considering innovation, instead of concentrating on isolated, individual choices. The message to managers is clear: look at the forest, not the trees - and get the overall design of your activity system right, before optimizing details. 